\title{
ORIGINS OF THE MCCLELLAN CAVALRY SADDLE USED BY SADF MOUNTED UNITS IN THE SOUTH WEST AFRICA CAMPAIGN AND ELSEWHERE
}

Nick Steele*

Contrary to predictions that the role of the horse in war was over when it was effectively replaced by mechanisation in the Second World War, it still plays a small but important role in military operations. In the late South West African campaign and now in unrest areas in the Transvaal and Natal the mounted infantrymen still perform a service in combat and in keeping the peace.

An interesting aspect of these military operations is that the SADF chose an American saddle of considerable fame for its mounted units. This is the McClellan cavalry saddle, the earliest version of which made its appearance in the United States Cavalry in 1859. (Fig 1)

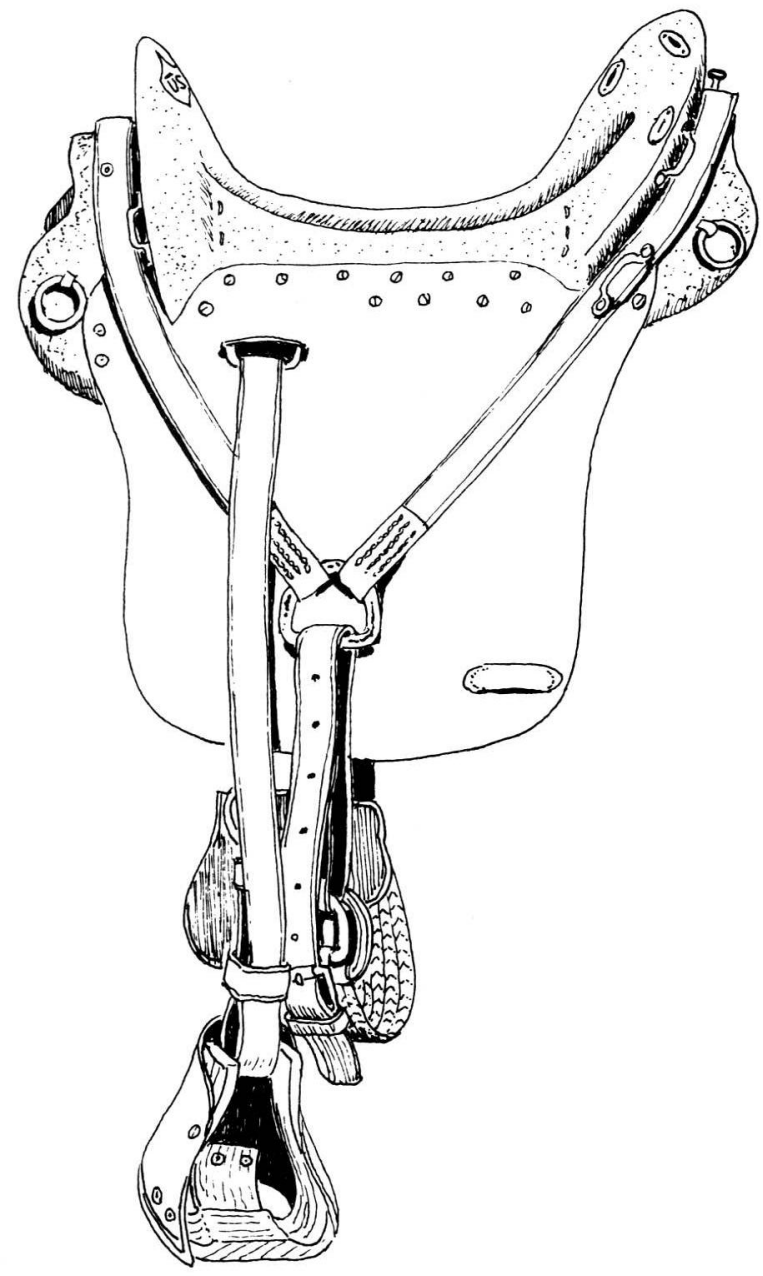

Fig 1 The first McClellan Saddle, 1859.
According to historian Randy Steffen, author of United States Military Saddles, in 1855 a Captain George B. McClellan, First Cavalry, later to become a general in the Civil War, (Fig 2) went to Europe as a member of a commission to study the armies of Europe and their equipment actively engaged at this time in the Crimean War. Captain McClellan claimed that his saddle was the result of an intensive study of European saddles, stating that he used the best features of the Hungarian and Mexican trees to perfect his design. However, this proved to be subterfuge on Captain McClellan's part. The saddle which took his name in fact incorporated the major features of the Grimsley, the Campbell and the Hope saddles also being tested by the military at that time. Despite this neither Campbell or Grimsley objected but this may only have been because they both died soon after McClellan's saddle was adopted.

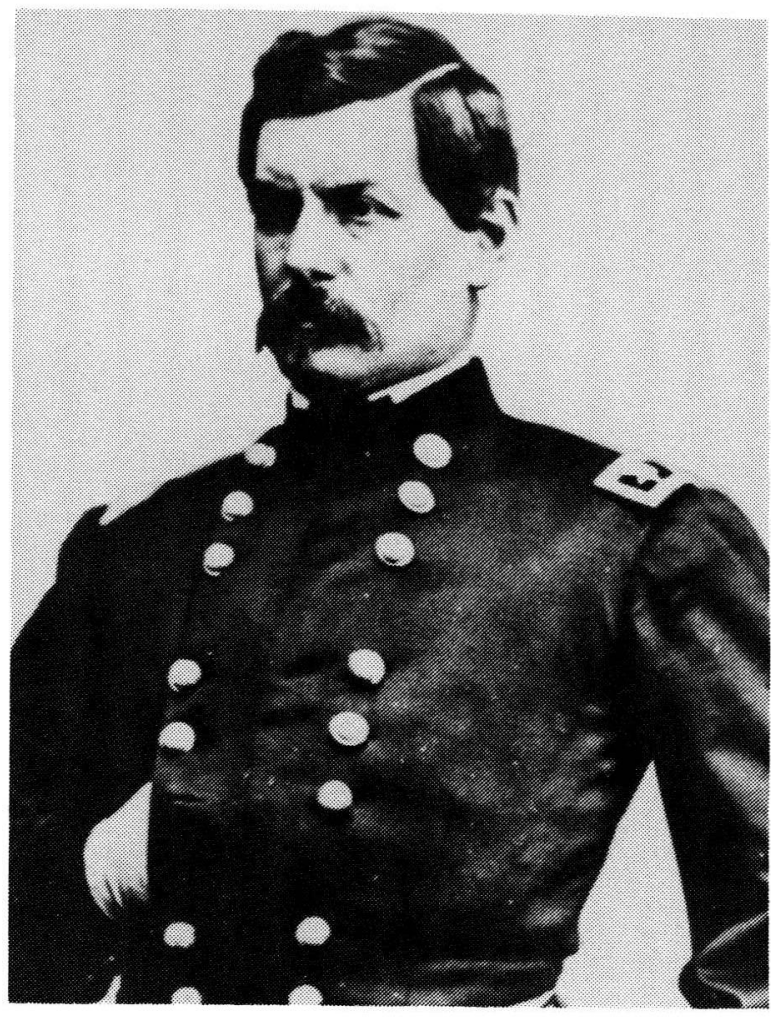

Fig 2 General George B. McClellan after whom the saddle was named. 


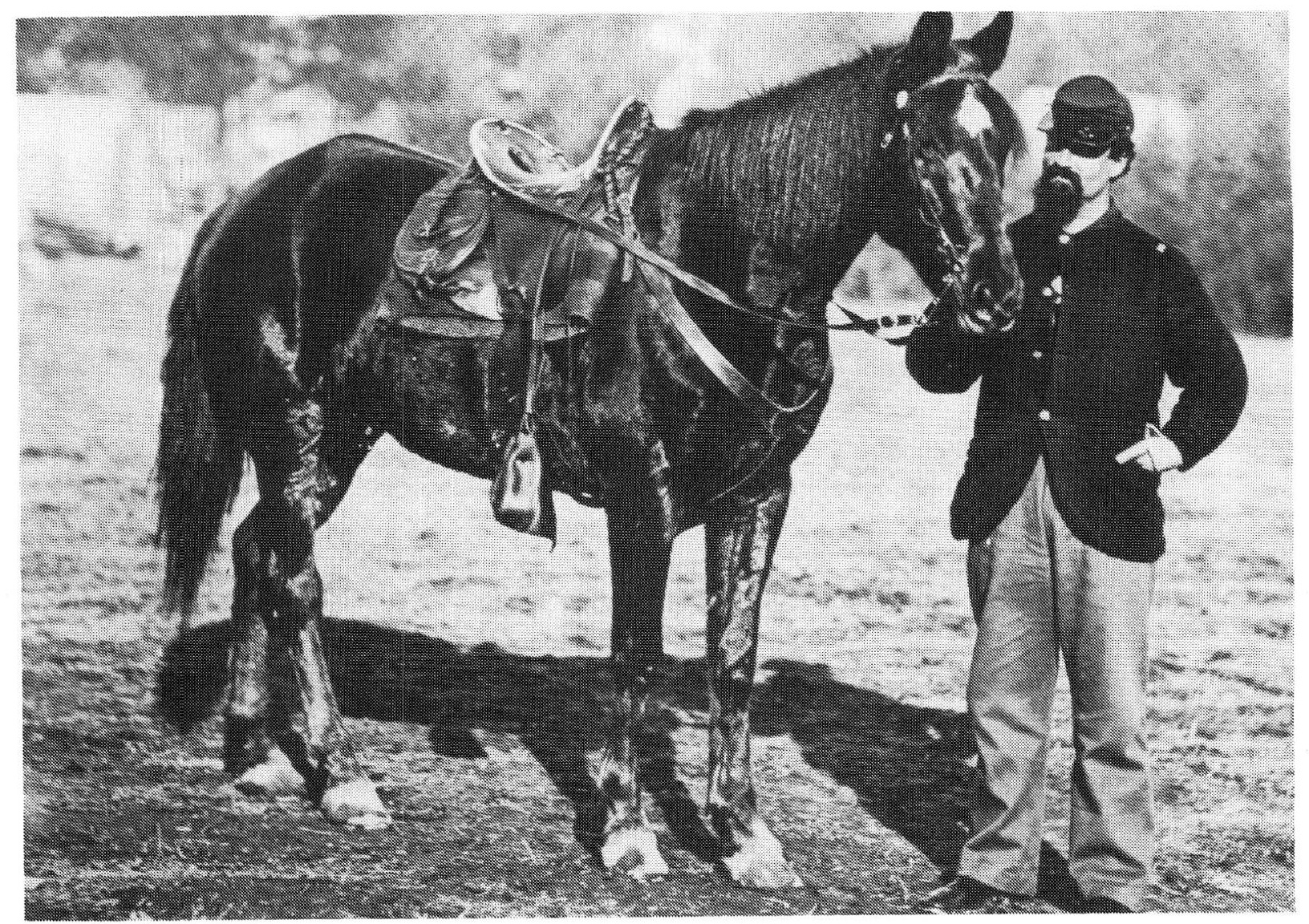

Fig 3 A Captain of the Northern Cavalry, American Civil War circa 1861.

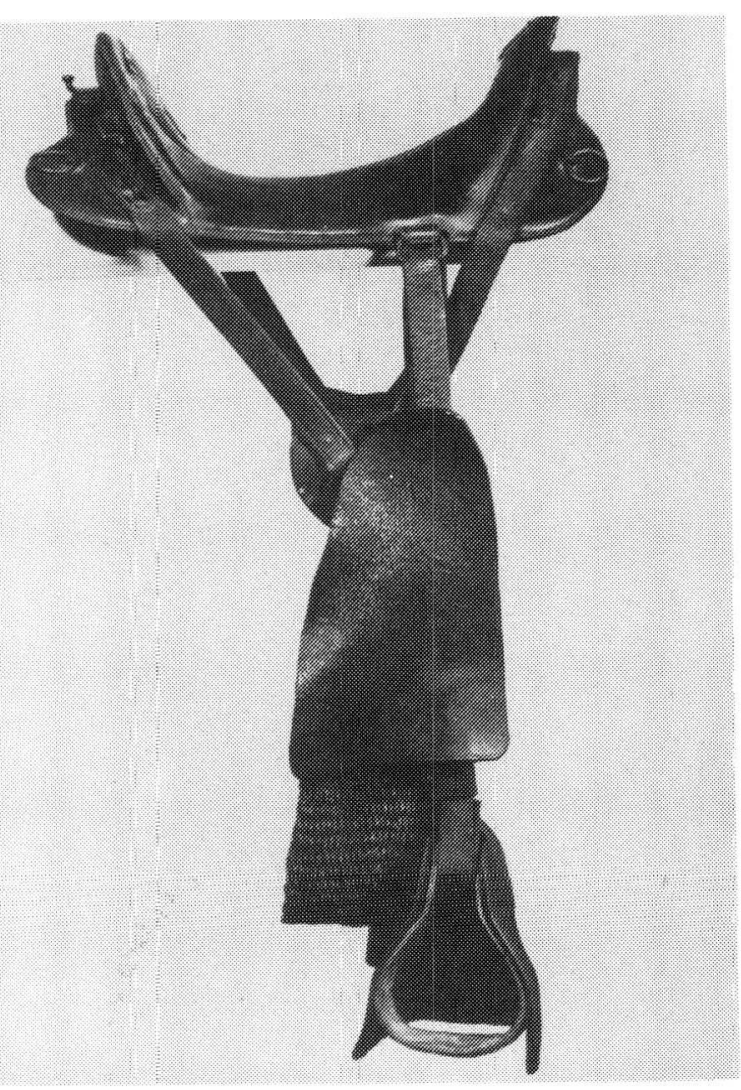

Fig 4 A McClellan saddle belonging to General George A. Custer, circa late 1860's early 1870's.

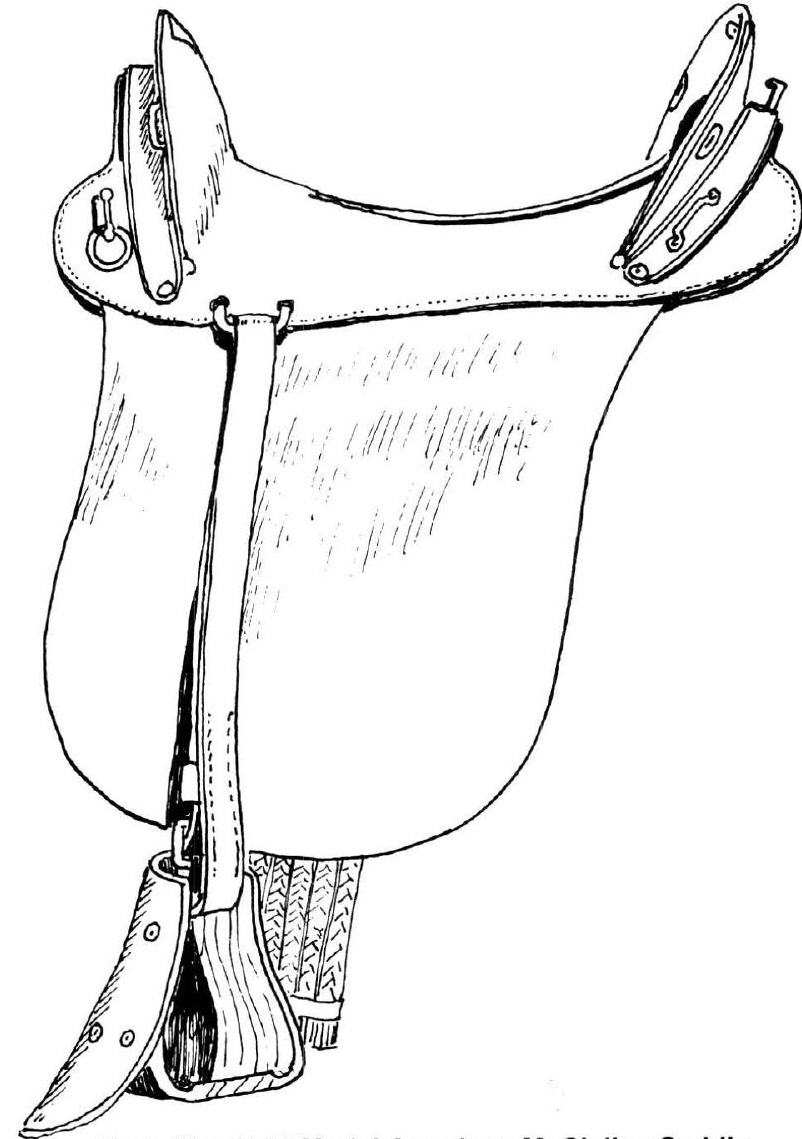

Fig 5 The 1928 Model American McClellan Saddle. 
The saddle shown in Fig 1 remained virtually unchanged for almost a hundred years of use by the United States cavalry. Steffen records that the original saddle had its skirts removed by that time but regained them in 1928 . The wooden tree of this saddle was first covered with leather ten years after its adoption. The stirrup hoods were taken off and put back several times and the girth rigging was only slightly changed a number of times. After this says Steffen, the McClellan remained the standard saddle for so many years not because better designs were not forthcoming but because of economics. Thousands of these saddles remained in military stores after the Civil War and the authorities could not consider the better designs while the vast stocks existed. Despite early flaws like split seams on the seat, which made them uncomfortable for the troopers, the McClellan was generally accepted as a good saddle, serving both northern and southern armies well (Fig 3).

By 1872 several important changes had already taken place to the McClellan. The saddle trees were covered with black leather and square leather safes were placed under the $D$ ring where the quarter girth straps met.

In June 1876 the famous United States Seventh Cavalry, commanded by General George A. Custer was equipped with McClellan saddles (Fig 4) when they advanced on the huge Indian confederation encampment on the Little Bighorn river, Montana. Of Custer's ill fated command of 210 officers and men at the battle of the Little Bighorn, there were no human survivors. Only one cavalry horse, a bay called Commanche was recovered by rescuers. The remainder were either killed, had to be destroyed because of wounds, fled into the wilderness or were captured by the Indians. Many McClellan saddles fell into Indian hands. For years after the battle they turned up in plundered Indian camps.

By 1879 many cavalry officers were of the opinion that the McClellan saddle should be replaced with a better saddle. Their main complaint being that the shape of the tree necessitated the rider having to "fork" the saddle which made it uncomfortable. For unknown reasons their complaints failed to bring about a satisfactory replacement and by 1885 the McClellan was still the official military saddle, the only change being that it was covered with brown leather instead of black leather.

Thousands of McClellan saddles were issued to British and colonial troopers in the Anglo-Boer War 1899-1902. Unfortunately these troopers were unaccustomed to them, tending to overload them with equipment. They were also unfamiliar with the girthing system. In one 2 week march a large number of horses withers were injured by that specific models' low, narrow gullet. After this they were discarded. The last modification of importance to the American model of the McClellan saddle was Model 1928 which was standard at the beginning of the Second World War. Ironically it resembled the old army saddle (see Fig 1) that had started off with skirts sixty nine years earlier.

This remarkable saddle has survived use for over 130 years (Fig 5) without major alterations. Although as an item of saddlery the McClellan has its detractors, it has numerous unique qualities, amongst which are its comparatively simple design and its durability. The current model used by the SADF has superior clinical qualities, especially for the horse. Unlike earlier models the gullet is deeper and wider, virtually eliminating the danger of pressure on the withers. The modified seat also provides more comfort to the rider. Fortunately for those concerned mounted infantry are here to stay into the forseeable future. So it seems is the McClellan saddle.

${ }^{*}$ Nick Steele is currently Director of the KwaZulu Bureau of Natural Resources

\section{BIBLIOGRAPHY}

Steffen, R. United States Military Saddles. Hutchins, J.S. Boots and Saddles at the Little Bighorn Johnson, S. History of the U.S. Cavalry.

Steele, N.A. Take a Horse to the Wilderness.

Gray, J.S. Centennial Campaign. The Sioux War 1876 